\title{
A critical theory of democratic agency: An interview with Eva Erman
}

\author{
Oyvind Stokke ${ }^{1}$ \\ Department of Philosophy, UiT The Arctic University of Norway, \\ oyvind.stokke@uit.no
}

DOI: http://dx.doi.org/10.5324/eip.v10i2.1929

(cc) BY

This is an open access article distributed under the terms of the Creative Commons Attribution 4.0 International License, which permits unrestricted use, distribution, and reproduction in any medium, provided the original author and source are credited.

\section{Introduction}

Eva Erman is a professor at Uppsala University and chief editor of Ethics \& Global Politics. Through several articles and books, including Political Equality in Transnational Democracy, co-edited by Sofia Näström (2013), and Territories of Citizenship, co-edited with Ludvig Beckman (2012), Erman has made important contributions to democratic theory and the analyses of political legitimacy beyond the centrality of the nation-states. Her research interests focus on political philosophy, meta-ethics, democratic theory, discourse theory, global democracy, and human rights. In 2012, Erman was a visiting research fellow at the School of Social and Political Sciences at the University of Melbourne, invited by the head of the school, Professor Adrian Little. In 2010, she was a visiting research fellow at the London School of Economics and Political Science (LSE), invited by the director of the centre, Professor David Held. She is currently working on the following projects:

(1) Democracy Beyond the Nation State? Transnational Actors and Global Governance and (2) Cosmopolitan Citizenship. ${ }^{2}$

In this interview, Erman clarifies basic concepts and distinctions in her research on democratic theory, discourse theory and global institutions, relating some of them to current issues. Asked to comment on the Arab Spring and Occupy, she contests the view that these movements demonstrate any kind of "democratic agency", but says they might be conceptualized as "agents of democracy" by improving the prerequisites for future democratization. Moreover, Erman stresses the analytic distinction between the ideals of democracy on the one hand, and the operations of certain power elites on a global scale undermining these ideals on the other. The important issue here is how we can limit the influence of private and non-state actors: Driven by capitalist aims, they do not represent democratic agency. In a similar vein, Erman acknowledges Jürgen Habermas's theorizing of normative principles from within society, while at the same time criticizes him for being unclear on the status of practical normativity within his reconstructed theory of modern capitalism. Critical theory, a normative theory, doesn't require a theory of society. However, Habermas's procedural theory of democracy delivers a better account of legitimacy than the dominant theories of distributive justice. Finally, Erman defends a role for the notion of truth within public deliberation. 


\section{Democracy and Global Social Movements}

Stokke: On behalf of the research group Pluralism, Democracy and Justice at The Arctic University of Norway in Tromsø, I would like to express my gratitude for having you here as a keynote speaker at the conference Realizing Global Justice. In a recent article, you write about democratic agency and democratic agents. Thinkers like Michael Hardt and Antonio Negri refer explicitly to the popular protest movements which mobilized against the old authoritarian regimes in Tunisia and Egypt in 2011, often referred to as the Arab Spring, as a new form of democracy. ${ }^{3}$ These movements are frequently said to have been the model for the Spanish Indignados protest movement, which recently marked its second anniversary. Indignados's occupation of public places and squares in Spanish cities was continued in the U.S. and other countries under the name Occupy. The common message from these movements was: "We are the owners of the public space-not the banks, the political class or the multinationals." Would you say that what we see here is the beginning of a new form of democratic agency, and even one that is not confined to the territory of the nation-state?

Erman: These movements are clearly not confined to the territory of nation-states as we commonly mean it; so in that sense, these movements transcend nation-state boundaries. However, whether this is the beginning of a new form of democratic agency is impossible to tell at this stage. In general, I think people have drawn too hasty and strong conclusions about the democratic implications of these movements. Concerning the so-called "Arab Spring", from a point of view of democracy, we know very little about the details, such as what kind of popular influence there has been, what kind of decisions have been taken, the kind of reasons and contestations that appeared in social media, and so on. I think much more empirical work needs to be done before we can draw any conclusions about that. We need to ask two questions: first, what role do these movements play if you generalize? And second, what role ought they play from the standpoint of democracy? The answer to the latter question is of course dependent on which conception of democracy one favours. Personally, I find the deliberative democratic model, or the Habermasian model, attractive. That model looks particularly interesting in this context, because it doesn't only focus on formal procedures of will formation through voting, but also on informal processes of opinion formation, contestations in public spaces and in the public sphere. So there we have something relevant, but I think what is often lacking in the present analyses of this, at least on the Habermasian model, is that these informal practices and contestations in social media, the protests and Occupy, would have to be channelled into the formal procedures to have democratic force. On this model, two tracks are thus necessary for democratic legitimacy, the formal and informal tracks. But in order for the latter to have a legitimating force, they would have to feed in to the former. However, what is common in the debate, which I find very unconvincing, is to think that the informal track somehow can replace the lack of a formal track (for example, in the form of little or no engagement through electoral voting that we see in many countries). I think that we can have a fully fledged informal track, i.e. an ideal situation where these protests and contestations are really distributed equally and not only by youth with computer access or whatever-and this does not say much 
about democratic legitimacy unless we know how this relates to formal decision making, where we take decisions that are binding. So there is nothing close to democratic agency involved here, I think. However, I have made a distinction in my work between "democratic agency" and "agents of democracy". This might be applicable here if we say that, while these protesters are not democratic agents now, from what we have seen, they may be conceptualized as agents of democracy if what we witness is the case in which they actually improve the prerequisites for future democratization. So they can actually create public spaces that might improve the prerequisites for the implementation or reorganization of democracy, which is something very different from being a democratic agent.

\section{The Rule of Law and the shadow elite}

Stokke: Let's turn to another current development in democratic politics. One problem here seems to be that the rule of law, which was meant to serve democracy and justice, under the circumstances of the current economic world order, often ends up by undermining these normative ideas. The anthropologist Janine R. Wedel presents an analysis of this development in her prize-winning book Shadow Elite. ${ }^{4}$ Here she documents how a new kind of power broker undermines democracy, law and even the market economy. This power elite operates in the shadows of official and formal political institutions. Wedel has coined a new term for this new breed of global players: flexians. These people wear different "hats" at the same time and operate at the margins of the law, and are experts on stretching the rules in order to serve purposes of economic or political influence. The problem seems to be the formal and informal influence of non-state and private actors in public regulations, to use one of your own phrases. Must we not also theorize such empirical developments in the political and economic sphere when we ask how the ideal of democracy is to be understood under globalized circumstances?

Erman: I like the notion of "flexians", and we can indeed see this under contemporary circumstances. However, I think we should separate the question of how globalized circumstances affect our understanding or conceptualization of the ideal of democracy from how such an ideal can be realized. So, I'm not sure whether flexians have anything to do with how we conceptualize global democracy. Of course, it's a complex issue, but why would they? While flexians cannot invalidate the ideal as such, I think, they can prevent its realization. In other words, I think there is an important difference between the formulation of principles of global democracy on the one hand, and their realization on the other. That said, it is a big issue in the debate on what role non-state and private actors should play. There seems to be an underlying premise, which I think should be unpacked and problematized much further, that we should find ways of making non-state and private actors democratically accountable in global politics and public regulation. I'm thinking here, for example, of the stakeholder approach to democracy or the growing literature on public-private partnerships, PPPs. To me, it's far from clear why these private actors should be included as democratic agents at all, even as agents of democracy. I don't see any justifications for it in the literature. It is often more of an underlying presumption that is made. Private actors are driven by capitalist aims and they could, of course, do a lot of good in the world, but their 
behaviour in economic actions primarily should be restricted, i.e. strictly regulated. The challenge, I think, is to delimit their power rather than to find ways to legitimate it. The literature on private-public partnerships focuses so much on how these actors can become more legitimate instead of asking why they should have that kind of political influence and power in the first place. Hence, before we can begin sketching principles for private-public partnerships, we must take on this challenge of how we can realize democracy in capitalist times. So that's the bigger question, and I think this requires a much richer understanding of the relationship between capitalist economic logic and democratic legitimacy and justice. And such an analysis must be made on a structural level. In the present debate, too much focus is directed at specific economic actors and their behaviour, which actually redirects attention to individual mistakes in the economic crisis that we witness today, rather than the overall systemic and structural problems involved in how capitalism affects democratic decision making.

\section{Capitalism and Critical Theory}

Stokke: Your answer actually points to the next question. In several works, your analysis is built on the discourse theory of Jürgen Habermas. One example is your dissertation, published by Ashgate in 2005 under the title Human Rights and Democracy. In Chapter $3^{5}$ of the book you critically revise crucial aspects of Habermas's theory of communicative action in order to avoid what you call "an implicit ethnocentrism built into the theory of modernity of the West"- an impressive task, I must concede. In effect, this revision leaves us with a Habermasian critical theory without a theory of society, if I have understood your book correctly. Now, the critical thesis in Habermas's magnum opus, The Theory of Communicative Action ${ }^{6}$, was that our common lifeworld is being colonized by the capitalist economy and bureaucratic power, but isn't this the kind of critical analysis that we need so urgently today? Is there not a need for counterbalancing the dominating trend of culturalism and discussions of the return of religion in liberal political theory with an updated political-theoretical analysis of the continuing uneasy relationship, or tension, between global capitalism and democracy? When governments facing massive interest rates demanded by global finance sell out common property like public services, natural resources and universities in order to balance their budgets, is this not an example of how the system imperatives of the capitalist economy encroach on areas of the lifeworld?

Erman: I think that a critical theory, even if it's not Habermas's theory, is a normative theory. It's about how we ought to arrange our societies. And the theory of social force is a sociological theory, or a theory of how things are. So, while we may agree that the lifeworld is being colonized by the capitalist economy-as part of a social theory, it is still an open question what this tells us in normative terms. What normative implications does it have? So, I think one of the fascinating and impressive features of Habermas's work, which has drawn me to it, is exactly his dual role as a social scientist and philosopher, thus always theorizing normative principles from within a theory of society and a theory of modernity. But this is also his problem. Since it is never clear what hat he has on, he tends to move from "is" to 
"ought" without clear motivations and justifications, from the social scientist to the philosopher and back again.

It's not clear to me why we must have a theory of society in order to develop a critical theory, say, in terms of a normative principle, to make it general. It is indeed helpful to rely on presumptions about human nature and society to theorize such a principle, but a theory of society in a thick sense is not necessary. Moreover, Habermas also moves freely between different kinds of normativity. A theory of communication, which is developed in that two-volume book that you mentioned, does not take us as far as we want to go in normative ethics. Normativity at the level of meaning is something different from practical normativity, which is concerned with what we want, or ought to do, how we ought to arrange our societies. This is the case, even if we find it plausible that communicative action is more genuine than strategic action, which he claims (explained by Habermas by the fact that strategic action is parasitical on communicative action). So, even if we were to agree on that, communication is about meaning and understanding Habermas's theory. It's no coincidence, I think, that Habermas left his moral theory, his discourse ethics, in which he tried to derive a moral principle (what he called the U-principle), from the principle of discourse (which he called the D-principle), anchored to a theory of meaning. That was a failed enterprise, and I think one of the reasons it failed was that he tried to derive practical normativity from a much thinner normativity of meaning. That said, I think understanding the workings of society may be important to theorize the normative principle, so I agree on that. Moreover, I also think that the better we understand our society, the more precise and accurate we may be in our assessments and judgements of how best to realize principles of justice or principles of democracy in practice. However, it's not clear to me why a certain theory of society would entail certain normative principles. This would be a very strong claim. The opposite might be the case, that certain principles call for radical reorganization of our society. When we theorize normative principles, we should, of course, look at the world and see which facts are bad and should not be accommodated by a principle. In cases where the principle does accommodate such facts, it's a bad or deformed principle that has to be revised. Note, though, that this argument is something different from the argument made by Cohen and others, that moral principles are ultimately fact-free, which is a meta-ethical point and, as such, of little assistance in normative theory. Thus, the claim that the content of justice may depend on facts about humans and society is compatible with claiming that justice so understood ultimately relies on fact-free fundamental moral principles. The emphasis on the actual circumstances of politics and the actual circumstances of society is crucial for a critical theory such as Habermas's, starting in real oppression and circumstances of injustices rather than an ideal about justice. But my point here is that we do not need a fully fledged theory of society to have a theory of justice or a theory of democratic legitimacy. Instead we must ask, in the light of the emphasis on actual circumstances of politics, how are normative boundary conditions established? If we claim that criteria of, say, democratic legitimacy are established by certain actual processes of those involved, then such a political order is legitimate insofar as it is in accordance with the process in question. But then, we also have started a famous regress, a process of regression or regress of justification. If all we do is adhere to a new actual process or arrangement, we are merely pushing the justificatory question one more step, not responding to 
it. So we need the normative wiggle room here to do normative political theory. The only way out of this is to acknowledge that not all normative sources of legitimacy are due to the actual circumstances, the context in which they are formulated. This is also the only reasonable starting point for a critical theory, even if it aims to take into account actual circumstances.

\section{Global Democracy and Global Justice}

Stokke: In a chapter on democratic agents and agents of democracy in your book Territories of Citizenship, ${ }^{7}$ you claim that democracy serves three aims: to provide democratic self-determination, to secure our interest in non-domination, and to promote distributive justice among citizens. Thus, as you further claim, we can resist an unwarranted dividing line between the debate on global democracy and on global justice. Now, this relationship between democracy and justice seems to vanish in some theories of justice. For instance, in Rawls's theory, the two principles of justice, which together define "justice as fairness", ${ }^{8}$ are free-standing, and democracy appears as the rule of the principles of justice. Can you explain more in detail how we could at least weaken this division, and how we should conceive of the relation between democracy and justice?

Erman: Justice theorists and democratic theorists have traditionally worked within very different paradigms, engaging in separate debates. One example is in the debate on global governance structures and international institutions in which I have been involved: I've been quite puzzled by the absence of dialogue between theorists of global justice and theorists of global democracy. When an exchange has taken place, and the relationship between them has been theorized, attention has been primarily directed at whether democracy is an intrinsically valuable ideal-mostly political scientists adopt that view-or whether democracy is primarily of instrumental value for achieving global justice, and that's more the view adopted by philosophers. I think there are several reasons why we should move beyond the distinction between intrinsic and instrumental justifications of democracy or justice for understanding the relationship between justice and democracy.

Instead, I think we must look at different conceptualizations of democracy and justice, and look at how different normative ideals accommodate these two conceptions, since they can be very different notions, depending on what view is put forward. On the standard view, a principle of justice establishes who owes what to whom-and this is Brian Barry's term ${ }^{9}$-and commonly expresses these entitlements through a set of rights. To the extent that principles of justice are about entitlements and rights, justice is primarily concerned with the moral quality of basic institutions, which is the typical Rawlsian view. And this has been very influential. Standards of justice indicate when institutions give their subjects exactly what they're entitled to: most importantly, when they respect their rights. This dominating view focuses on distributive justice and on rights.

In contrast to justice, however, which is supposed to account for who owes what to whom, the primary normative relations for political, or democratic, legitimacy is not between individuals simpliciter, but between rule-makers and rule-takers, between decision-making bodies and those that are supposed to abide by their 
decisions and laws. So, personally, I think it is far from clear how the theory of distributive justice can transform into a theory of democratic legitimacy. The task of legitimacy is not to tell us when a political institution gives its subjects what they are owed, but to tell us when this institution has the right to rule and the right to be obeyed. So, in contrast to justice, democratic legitimacy is a two-way relationship rather than a one-way relationship. It's not foremost about the distribution of entitlements and rights, about being a recipient of goods, but about intersubjective relations and structures, the justifiability of political relations. Rather than being the recipients of legitimacy, subjects achieve legitimacy, which requires the authorization of political power and political agency of a particular sort. The basic point is this: independent of whether democratic legitimacy is expressed in terms of substantive demands of distributive justice, this is not sufficient because legitimacy requires procedural criteria. So even if justice and democracy might be grounded in the same egalitarian liberal principle of equal worth or something, they are distinct values, and should be treated as such. From my point of view-inspired by discourse theory-justice in democracy is not about distributive justice, but ultimately rests on the idea of justice as justification, as a right to justificationwhich is the reason why democratic legitimacy may be described as a kind of procedural justice-if we use the concept of justice; but this is not the dominant notion of justice.

Stokke: What you say here now reminds me of Rainer Forst's theory of justification, when he also stresses the point that there should be structures of justification in place. And this is different, as you say, from looking at individuals only as recipients of goods. We need structures of justification in order to make individuals into democratic agents. So I think you're really much in line with his thinking here.

Erman: And this can be grounded in many ways, but for me it's grounded in the equal respect of autonomous agency, so it's very agency-based. Which is Forst's view too, I think.

\section{Epistemic Democracy and Responsible Decision-Making}

Stokke: A current debate within democratic theory concerns the epistemic dimension, or value, of democracy. The concept of epistemic democracy has found its most prominent normative justification in the work of David Estlund ${ }^{10}$, and points basically to the claim that participation is not enough because decisions also have to be reasonable or informed or qualified with regard to some epistemic standards. At the same time, epistocracy opens up for "expertocracy", or the rule of experts. To cite from the presentation of the new research project on epistocracy at the Centre for European Studies at the University of Oslo, "To deal with the risks and the hazards globalization throws upon us, the best available expertise must be mobilized and given the necessary power, even if we, by doing so, are challenging familiar ideas of democracy." ${ }^{11}$ How would you assess this clear dilemma, and how are we going to balance the moral claim of democracy-that everybody should have an equal possibility to participate in decision making on the one hand, and the epistemic claim that decisions should be qualified according to some epistemic standards, on the other? 
Erman: From what you quoted, it may well be true that dealing with risks and hazards requires experts. But to claim that this is a new form of democracy requires an argument. We may argue that due to some immediate and severe risks, such as environmental harm, we should actually prevent, or limit democratic participation because there are some decisions that have to be made very quickly and experts can do it. But that is not to say that we have another democratic channel; it's just to say that democracy is not the only ideal that we care about. We have many problems to solve. So, a more upfront way for "epistocrats" would be to say that expert rule might trump democratic decision making under certain circumstances. The challenge that remains is, however, to argue that actually doing so would increase democracy in a "new way". For sure, one can argue that truth matters for public deliberation and democracy, that is, that democracy is valuable for epistemic reasons, since we tend to take more stable and well-grounded decisions with democratic rule-making than alternative decision procedures. But to ground democracy entirely on epistemic principles is unconvincing. In my view, it cannot replace a normative grounding that involves moral values.

That said, I've never understood why democratic theorists are afraid of discussing the role of truth in democracy. One reason why Rawls insisted that political liberalism is doing without the concept of truth was the doctrinal pluralism, i.e. the modern conditions of incompatible comprehensive doctrines. That was his justification for the thesis that political liberalism should do without a concept of truth. So, Rawls's worries about truth derive from the aim of political liberalism to be freestanding from a wider set of philosophical or religious commitments. So democracy's public reason, as he puts it, consists of a place, a common platform of values that can be reasonably shared by people who regard themselves as free and equal, but have irreconcilable doctrinal disagreements about, say, justice. However, I have never really understood why normative ideals about justice, liberty, democracy or equality have a place in public deliberations or public reason, but not truth. Rather, if we are concerned with justice in our practical deliberations in democracy, we should be concerned with getting it right, and if we're concerned with getting it right, we are concerned about truth about justice. To me, it seems difficult for any plausible notion of public reason to accommodate ideas about judgements, assessments, and assertions in public argument while excluding the notion of truth. For example, believing $\mathrm{X}$, on the view I'm taking here, means believing $\mathrm{X}$ is true. Even if truth is not a necessary condition for acceptability of public justification, I think the role of truth in practical deliberation and public reasoning is essential just because of these aspects: we want to be able to make use of notions such as judgement, assessments, assertions. What I take Rawls to be saying, actually, is rather that we in democratic public deliberation should steer away from the larger philosophical questions about the nature of truth. This sounds about right. I am not a Rawlsian, but I think, or hope, that Rawls's claim about the concept of truth being unavailable meant precisely this: that public reason should not be concerned with the nature of truth. I think, actually, that Habermas misunderstands this in their famous exchange when he claims that Rawls's political liberalism cannot avoid issues of truth. While I agree with Habermas that it needs to accommodate the notion of truth in the role that I pointed out earlier, I think it should avoid questions about the nature of truth. Democratic deliberation is, in the end, about collective decision making and common deliberation on practical decisions. 


\section{Notes}

${ }^{1}$ Øyvind Stokke is an associate professor at the Department of Philosophy, UiT The Arctic University of Norway. Stokke regularly teaches courses on global justice and social philosophy. His last publication on the topic is "On the democratic value of common goods", in: Alnes, J.H., Toscano M. (Eds.), Varieties of Liberalism. Cambridge: Cambridge Scholars Publishing (2014): pp. 150-171.

The interview was held on June 23, 2013, at UiT The Arctic University of Norway, on the occasion of the international conference on Realizing Global Justice: Theory and Practice. This interview is part of a series of interviews with the keynote speakers. The conference and the interview series were organized by the Pluralism, Democracy, and Justice Research Group funded by the Justice in Conflict Project (2010-2015), Research Council of Norway, in collaboration with the Brazilian magazine Filosofia Ciência \& Vida, edited by Paula Palma Félix.

${ }^{2}$ For more information about the projects, visit the website www. transdemos.se or her personal webpage at Uppsala University.

${ }^{3}$ Hardt and Negri (2012), p. 2.

${ }^{4}$ Wedel, Janine R. (2009). Shadow Elite. New York: Basic Books.

${ }^{5}$ Erman (2005), pp. 69-119, esp. p. $77 \mathrm{ff}$.

${ }^{6}$ See Habermas (1984/87), vol. II. This work could best be read as an ambitious interdisciplinary research programme for a critical social theory, integrating insights from speech act theory, classical sociology, symbolic interactionism, and Parsonian systems theory in an analysis of the action coordinating energies of language at the core of our social order. In subsequent volumes Habermas develops a discourse theory of ethics, law and democracy, culminating in Between facts and norms. Contributions to a discourse theory of law and democracy in 1992 (1996).

${ }^{7}$ Beckman, L., Erman, E. (2012). Ch. 4, pp. 60-80.

${ }^{8}$ Rawls (2005), p. 60.

${ }^{9}$ See Barry $(1989,1995)$.

${ }^{10}$ See Estlund (2007).

${ }^{11}$ Quoted from the official website of EPISTO, a five-year research project on epistemic democracy in multi-level governance, hosted by the Centre for European Studies at the University of Oslo. See link: http://www.sv.uio.no/arena/english/ research/projects/episto/index.html.

\section{References}

Barry, B. (1989). Theories of justice. Berkeley: California University Press.

Barry, B. (1995). Justice as impartiality. Oxford: Oxford University Press.

Beckman, L., Erman, E. (Eds.) (2012). Territories of citizenship. London and New York: Palgrave Macmillan.

Erman, E. (2005). Human Rights and Democracy. Discourse Theory and Human Rights Institutions. London: Ashgate.

Erman, E., Näsström, S. (Eds.) (2013). Political Equality in Transnational Democracy. London and New York: Palgrave Macmillan.

Estlund, D. (2007). Democratic authority. A philosophical framework. Princeton: Princeton University Press. 
Habermas, J. (1984/87). The Theory of Communicative Action, vols. I-II. London: Polity Press.

Hardt, M., Negri, A. (2012). Declaration. New York: Hardt and Negri.

Rawls, John ([1971]2005). A theory of justice. Cambridge: Harvard University Press. Wedel, Janine R. (2009). Shadow Elite. New York: Basic Books. 